\title{
Secondary School Students’ Perceptions About Space Camp: Space Camp Turkey
}

\author{
Selin Kulegel ${ }^{1} \&$ Unsal Umdu Topsakal ${ }^{1}$ \\ ${ }^{1}$ Department of Mathematics and Science Education, Faculty of Education, Yildiz Technical University, Istanbul, \\ Turkey \\ Correspondence: Selin Kulegel, Mathematics and Science Education, Yildiz Technical University, Istanbul, \\ 34220, Turkey. E-mail: selin.kgel@gmail.com
}

\author{
Received: April 18, 2020 Accepted: May 23, 2020 Online Published: May 28, 2020 \\ doi:10.5539/jel.v9n3p154 URL: https://doi.org/10.5539/jel.v9n3p154
}

\begin{abstract}
The aim of this research is to investigate the effects of outdoor learning environments such as space camp on the perceptions of secondary school students about astronomy, career choices, and development of 21 st century skills. Izmir space camp trip was organized in 2019. Qualitative study was conducted with secondary school 5th grade students attending the space camp $(\mathrm{N}=24)$. Semi-structured interview form, focus group interview, space camp evaluation form and researcher observation notes were used as data collection tools. Data analysis was evaluated with content analysis and open coding. Students participated in the program of stars and planets adventure. In this program, the participants had the opportunity to use astronaut training simulators that give the feeling of living and working in space, to perform simulated shuttle missions, to learn new information from experts in the field and to get more detailed information about the professions. At the end of the study, it was revealed that out of school learning environments such as space camps had a positive effect on students. As a result of the study, it has been observed that the students perform their duties in a team collaboration in shuttle mission and develop their critical, questioning and thinking skills by experiencing the discussions about the subject with the experts. In addition, the misconception about Pluto was also determined.
\end{abstract}

Keywords: space camp, astronomy education, outdoor education, outdoor learning environments, science education

\section{Introduction}

\subsection{Outdoor Learning Environments}

Out-of-school learning environments are learning environments organized outside the classroom for a specific educational purpose, which are realized with the active participation of students and increase their interest and curiosity (Plumber, Schmoll, Chun Yu, \& Ghent, 2015). Students have the opportunity to learn while traveling. Out-of-school learning environments contribute positively to students' curiosity towards science, to question events, to understand concepts and to show an interest in activities (NRC, 2009). Major out-of-school learning environments; science centers, planetariums, zoos, botanical gardens, aquariums, science museums and space camps.

\subsection{Astronomy Education}

Astronomy is an integrated field with science that contains topics that are difficult to reach, complex, abstract and require three-dimensional thinking on our blue planet. We can give this as an example to scientists who have been interested in both science and astronomy in the past, such as Galileo, Kepler, Newton and Copernicus. These scientists made inferences based on current conditions using scientific methods (Betz, 2011; Padalkar, 2010). Astronomy has played an important role in discovering and making sense of the universe throughout history. It made important contributions to students in curiosity, discovery, developing their imagination and looking from a holistic perspective (Percy, 2006).

\subsection{Space Camps as an Outdoor Learning Environment in Astronomy Education}

Space camps, seen as a form of informal learning environments, create opportunities for children to share their interests, curiosities, questions, and enable students to choose role models in science-related career choices. 
In most studies (Aktamıs, Acar, \& Unal Coban, 2015; Henstock, 2014; Kinsner et al., 2011; Deborah Anne Fields, 2009; Tal, 2004), it can be said that space camps have an effective out-of-school learning environment and are of great importance in the development of students' skills.

The aim of this paper is to examine the effects of out-of-school learning environments such as space camp on the perceptions of secondary school students on astronomy, career choices and the development of 21 st century skills.

\subsection{Research Questions}

1) Will space camp trips improve students' astronomy skills?

2) Do space camp trips have an impact on career choice?

3) Do space camp trips have an impact on the development of 21 st century skills?

4) Do space camp trips have an effect on teaching astronomy concepts?

\section{Method}

\subsection{Model of the Research}

This study is based on the case study method, which is one of the qualitative research models. Case study; It is a method where a single situation or more events are examined in detail, the data are collected systematically and what is happening in the real environment (Davey, 1991).

\subsection{Description of the Space Camp}

The students participated in the program of stars and planets on a space camp trip in Izmir. This camp lasted for 3 days with accommodation. The main objectives of this program are to educate young people in space sciences, to encourage teamwork through space simulations, and to provide students with the feeling of being in space by performing simulated shuttle tasks.

During the 3-day training, the participants observed how the plants could grow in hydroponic environment, and looked at the constellations. They performed the tasks given using the astronaut training simulators, which gave the feeling of living and working in space.

\subsection{Participants}

A space camp trip was organized for 3 days in 2019 with the participation of 6 teachers and 60 students studying in a private secondary school in Istanbul. In order to determine the study group of the research, criterion sampling type was applied from the purposeful sampling method. For this purpose, 24 students, who are 10 years old, studying in the 5th grade class of 60 students, constituted the sample group of the research. In the study, the criterion sampling method was preferred since the criteria were determined by the researcher and a study group was formed according to these criteria.

\subsection{Activities}

The activities of the participants were shaped according to certain thematic purposes related to space. These purposes are generally; Educating young people in space sciences is like promoting teamwork through space simulations and performing simulated shuttle tasks. Thanks to this trip, students were developed in every sense (cognitive, affective and psychomotor). The activities of the camp are as follows:

On the first day of the camp, students were told about the program and rules of the camp. Students were divided into teams such as Sun, Mercury, Venus, Earth, Mars, and an instructor was at the head of each team. They had the opportunity to experience a program indoors with fields such as space sciences, science, mathematics, technology and astronomy. First, they watched a documentary about space in the planetarium. Fun experiments were presented. Then they made a hot air balloon. They received flight mission training. Each team member had a role in this flight mission, and acted in team work. In addition, students produced electrical energy from various fruits at the makey makey station (robolab). When it got dark, they made observations with a telescope.

On the second day of the camp, Participants learned the constellations in the Galileo class, they got to know the space suits, got dressed and got on the Mars exploration vehicle. By observing the place where hydroponic agriculture is done, they got information about plants. They thought what could be done on Mars. Afterwards, students had the opportunity to experience with $1 / 6$ Gravity seat simulator, zero gravity wall simulator, space station motion training simulator, multi-axis simulator and hurricane $360 \mathrm{VR}$ simulator. Excitement and happiness appeared on the faces of the children in each simulator. In addition, students threw the hot air balloon they made yesterday. 
On the third day of the camp, the participants learned from the instructors about the professions apart from in-depth science knowledge. In addition, students learned what astronauts are eating in space and how important recycling is. The member in a team had a certain responsibility and profession. The teams worked on graduation scenarios and the graduation ceremony took place.

\subsection{Instrumentation}

In this research, semi-structured interviews, focus-group interview, space camp evaluation form and researcher observation notes, which are among qualitative research data collection tools, were used.

Semi-structured interviews were implemented at the end of the 3-day camp period to reveal students' thoughts on astronomy and space sciences. In this research, there are 7 open-ended questions that were developed by the researcher by seeking literature review and consulted for expert opinion. These questions were created on the basis of the concepts of astronomy, planet and astronaut. Different questions were asked according to the flow of the conversation.

Focus-group interview was conducted to examine the participants' perceptions about the content, implementation and skills acquired at the end of the camp. One student from each team attended, and students were interviewed for 15 minutes. In order to gain experience in group meeting and to feel more comfortable, a trial group meeting was held. Then, the main interview was started, and the interviews were recorded by recording the sound.

Space camp evaluation form was designed to examine participants' views on their activities in the space camp. This form consists of 4 open-ended questions developed by the researcher through a literature review and consulted with expert opinion. Space camp evaluation form consists of questions such as what did you learn on space camp trip? What was the fun side of the activities? What was the boring part of the activities? and What would you like to change?

Researcher observation notes were used to reveal students' thoughts on space camp during the application process. When the researcher was not involved in the activities, she observed the students, and got the necessary notes. The researcher diversified the observation data by taking photos of the students and taking sound recordings.

\subsection{Data Analysis}

Students' views on the activities are reported individually for each student. The organization of the data was carried out in a computer environment and the data obtained from the interviews, document, and observation tools were classified. Qualitative data obtained from interviews and forms were analyzed by content analysis. The responses of the participants were analyzed by two researchers using open coding. The researchers discussed and presented the codes in tables. It was aimed to bring together the statements that have similarities and differences and to ensure the reliability of the research. In order to increase the reliability and validity of the research findings, the opinions of the students were included under the themes with direct quotations. In order to determine reliability in content analysis, consistency between encoders is generally calculated. Considering that the researchers have chosen the same answer option for the relevant question, they will be accepted as consensus, and if they have marked different options, they will be accepted as a difference of opinion; Percentage of Coherence (Encoder Reliability Coefficient $=$ Consensus/Disagreement) x 100 formula was used (Miles \& Huberman, 1994). The ratios of .70 and above were calculated reliably for each theme. According to Yildırım and Şimşek (2005), when the agreement percentage in reliability calculation is $70 \%$, it is accepted that the reliability percentage has been reached. Accordingly, the reliability coefficient between the coders was calculated using the formula in the study, and the agreement rate in all questions was calculated as .80 . Considering these rates, it can be said that the reliability coefficient between encoders is sufficient. In order to make the study ethical, students' identity is hidden. They were given code to each of the students and named as S1, S2, S3 etc.

\section{Results}

Semi-structured interview was implemented at the end of the 3-day camp period to reveal students' thoughts on astronomy and space sciences. Data were examined under 5 themes and 8 categories. 
Table 1. Analyzing of semi-structured interview

\begin{tabular}{|c|c|c|c|}
\hline Theme & Category & Code & Frequency \\
\hline \multirow{21}{*}{$\begin{array}{l}\text { Positive Aspects of } \\
\text { Astronomy }\end{array}$} & \multirow[t]{8}{*}{ Being an Astronaut } & Make it look Fun & 3 \\
\hline & & Examining the Earth from Space & 1 \\
\hline & & Exploring unknowns about Space & 5 \\
\hline & & Wondering the Space & 3 \\
\hline & & Go to a different Planet & 2 \\
\hline & & love Space & 3 \\
\hline & & No Gravity & 4 \\
\hline & & Seeing the dimensions of the Planets in Reality & 1 \\
\hline & \multirow[t]{13}{*}{ Fun side of Astronomy } & Observing & 2 \\
\hline & & Arousing curiosity & 3 \\
\hline & & Go to space & 2 \\
\hline & & Simulators & 2 \\
\hline & & Providing information about the Future & 1 \\
\hline & & Giving information about the names of Celestial Bodies & 2 \\
\hline & & learn new information & 2 \\
\hline & & Planets & 3 \\
\hline & & Constellations & 1 \\
\hline & & Wander & 1 \\
\hline & & Be mysterious & 1 \\
\hline & & Flight Mission in Teamwork & 1 \\
\hline & & Be Mobile & 1 \\
\hline \multirow{18}{*}{$\begin{array}{l}\text { Negative Aspects of } \\
\text { Astronomy }\end{array}$} & \multirow{12}{*}{ Not Being an Astronaut } & Stay away from People You love & 3 \\
\hline & & Fear of being Alone in Space & 1 \\
\hline & & long Road & 2 \\
\hline & & Missing People You love & 2 \\
\hline & & Risk of Death & 3 \\
\hline & & Get lost in Space & 3 \\
\hline & & Be Afraid of Black hole & 1 \\
\hline & & Dangerous & 4 \\
\hline & & life in Space is difficult & 3 \\
\hline & & a difficult Job & 3 \\
\hline & & No Gravity & 2 \\
\hline & & No Water & 1 \\
\hline & \multirow[t]{6}{*}{ Boring Side of Astronomy } & Waiting during the observation & 3 \\
\hline & & More information & 2 \\
\hline & & Complex information & 1 \\
\hline & & Too much Obscurity & 2 \\
\hline & & Difficult to Satisfy Toilet Needs in Space & 1 \\
\hline & & Horoscope & 1 \\
\hline \multirow[t]{8}{*}{ Astronomy contents } & Incorrect Information & Pluto & 1 \\
\hline & \multirow[t]{7}{*}{ Interesting Planet } & Mercury & 3 \\
\hline & & Earth & 5 \\
\hline & & Mars & 3 \\
\hline & & Jupiter & 4 \\
\hline & & Saturn & 5 \\
\hline & & Uranus & 1 \\
\hline & & Neptune & 2 \\
\hline \multirow{13}{*}{$\begin{array}{l}\text { Teaching Method of } \\
\text { Astronomy Contents }\end{array}$} & \multirow[t]{13}{*}{ Teaching Method } & Telling more of the Planets and Stars & 2 \\
\hline & & Teaching by Fun and Playing Games & 4 \\
\hline & & Kinesthetic & 1 \\
\hline & & Teaching by Comparison & 1 \\
\hline & & Quick expression & 2 \\
\hline & & Suitability for the child's level & 1 \\
\hline & & Educative & 1 \\
\hline & & With simulator & 3 \\
\hline & & Explanation towards Goal & 2 \\
\hline & & More Comprehensible Expression & 3 \\
\hline & & Teaching like in Space Camp & 3 \\
\hline & & Different Method & 2 \\
\hline & & the Same Method & 1 \\
\hline \multirow{8}{*}{$\begin{array}{l}\text { The importance of Trips } \\
\text { on the Subject of } \\
\text { Astronomy }\end{array}$} & \multirow[t]{8}{*}{ Importance of Trips } & Get information & 7 \\
\hline & & Developing the Horizon at an Early age & 5 \\
\hline & & Fun learning & 3 \\
\hline & & Supporting Science Course & 3 \\
\hline & & learn about Professions & 4 \\
\hline & & Be interesting & 1 \\
\hline & & Giving information about Astronauts & 3 \\
\hline & & & 158 \\
\hline
\end{tabular}


The answers given by the students for Table1 differ in terms of each category. When we look at the "Being an astronaut" category, the most common answer is "exploring unknowns about space"; In the "Not being an astronaut" category, the most common answer is "dangerous".

S4: I want to be an astronaut because I would like to discover puzzlers about space.

S19: I want to be an astronaut because I want to try zero gravity.

S11: I don't want to be an astronaut because we may not go back. It is very dangerous and black holes scare me.

S5: I don't want to be an astronaut because even going to the nearest planet takes a long time and I miss my family.

It is seen that a student gave the Pluto answer under the category "incorrect information".

S21: Pluto. I want to go there because it is a very distant and very small planet.

When the "Interesting planets" category is analyzed, the highest answers were "Earth" and "Saturn".

S15: The most interesting planet is Earth because people live on it.

S19: The most interesting planet is Saturn because its ring attracts my attention.

Focus-group interview was conducted to examine the participants' perceptions about the content, implementation and skills acquired at the end of the camp. The answers given by students as a result of the focus group interview are shown below.

Researcher: What have you learned in general on a space camp trip?

S1: We learned a lot about space.

$\boldsymbol{R}:$ What, for example? If you give an example?

S2: We learned about life in Mars, hydroponic agriculture, conductive \& insulator, how to fly, how to walk, and feel

S4: We felt in an environment without gravity.

S3: We saw how to play sports in space.

$\boldsymbol{R}:$ What was the most positive effect of the trip? Why is that?

S1: getting on the simulators, entering flight training because we did fun things in flight training. We were always in communication with our teammates. We have also experienced new things in simulators.

S2: We tried things we couldn't feel in simulators in real life. In flight training; we have seen what a profession that we normally cannot be now or what a profession we can learn.

S3: We learned different information. The camp was really educative.

S4: By doing what astronauts do in space, we had the opportunity to understand them.

$\boldsymbol{R}:$ You might say it would have been better at the camp?

S2: The simulators to be tried could not be ridden because there were too many groups.

S1: We got on 2. We could ride 3 or 4.

S4: The room with star observations was very nice, but the science lab room was bad. There were computers, but it was very small.

S3: There was something like dancing there. We did it.

R: Finally, what would you like to say about the camp?

S1: It was nice, it was fun.

S2: You can go as a family. There are summer camps. It can be visited as a school. The camp was really good.

S3: Simulators were very fun.

S4: Simulators were definitely the best of the camp.

When the dialogue between the researcher and the students is examined, "S2: We tried things we couldn't feel in simulators in real life. In flight training; we have seen what a profession that we normally cannot be now or what a profession we can learn." and "S1: getting on the simulators, entering flight training because we did fun things in flight training. We were always in communication with our teammates. We have also experienced new things in simulators." The answers show that the camp gains skills such as career awareness, team work. 
Space camp evaluation form was designed to examine the participants' views on their activities in the space camp. Themes, categories and codes obtained from the camp evaluation forms are presented in Table 2.

Table 2. Analyzing of space camp evaluation form

\begin{tabular}{|c|c|c|c|}
\hline Theme & Category & Code & Frequency \\
\hline \multirow[t]{8}{*}{ Fun Aspect of Activities } & Cognitive Domain & learn different Information & 4 \\
\hline & & Be Educative & 5 \\
\hline & Motional Domain & Experience different Simulators & 12 \\
\hline & & Enter the Space Station & 1 \\
\hline & Team work & to do Flight Mission & 3 \\
\hline & Affective Domain & Understanding Astronauts & 2 \\
\hline & & Understanding life in Space & 3 \\
\hline & Other & Good Instructors & 1 \\
\hline \multirow[t]{5}{*}{ Boring side of activities } & About Simulators & Simulators are too mobile & 1 \\
\hline & & Waiting for Simulator queue & 3 \\
\hline & Demonstration & Experiment Presentation & 2 \\
\hline & & Hydroponic Agriculture & 2 \\
\hline & Clothing & Astronaut Outfits & 1 \\
\hline \multirow[t]{4}{*}{ Wanted to Change } & About simulators & Riding More Simulators & 5 \\
\hline & & Slower Movement of the Simulator & 2 \\
\hline & & Stay in the Simulator for longer & 3 \\
\hline & Peer Behavior & Quieter peers & 2 \\
\hline \multirow[t]{11}{*}{ Information Gained at the Camp } & Celestial Bodies & Planet & 2 \\
\hline & & Star & 2 \\
\hline & & Constellation & 3 \\
\hline & Astronaut & Astronaut Costumes & 9 \\
\hline & & Training of Astronauts & 1 \\
\hline & & What Astronauts Eat & 7 \\
\hline & Future Applications & Going to Mars & 2 \\
\hline & & life in Space & 6 \\
\hline & & Hydroponic Agriculture & 1 \\
\hline & About Simulators & Simulator & 3 \\
\hline & & & 88 \\
\hline
\end{tabular}

In Table 2, when the opinions of the participants are examined in terms of each category, when we look at the "Motional domain" category, the most common answer is "experience different simulators"; In terms of "boring side", it is seen that the most frequently said answer is "waiting for simulator queue".

S9: Simulators and flight mission are the most fun. Because we have experienced what astronauts live.

S5: Waiting in line while getting on the simulators was the most boring part. It would be better if there were a few more from a simulator.

The theme of "information gained at the camp" was examined under 4 headings: Celestial bodies, Astronaut, Future applications and About simulators. The vast majority of the responses were related to astronauts. (astronaut costumes $\mathrm{f}=9$, what astronauts eat $\mathrm{f}=7$ )

S23: I learned the things that astronauts wear, eat, drink.

S18: I learned about astronaut clothes, how astronauts live in the space station, what simulators like SSMT and MAT do, air balloon construction, flight missions, what flight engineer and shuttle commander do, constellations, some experiments and much more.

Researcher observation notes were used to reveal students' thoughts on space camp during the application process. It is important for the camp to have rules, to give students a sense of responsibility and to plan the time of the student. Most of the students stayed away from their families for the first time and this situation enabled them to gain self-confidence. In addition, students' leadership skills have increased. they understood the importance of team work. they had practical space experiences. In addition, positive effects such as happiness and excitement were observed in the eyes of children throughout the camp. the camp has increased students' interest and curiosity in space and astronomy. They developed their problem-solving skills by pushing the limits of their imagination. 


\section{Discussion}

The aim of this study is to explore secondary school students' views on astronomy, career choices and 21 st century skills during space camp activities. The results from the data are shown below.

According to the results, researcher observation notes, interviews and space camp evaluation forms also provide similar evidence. It was seen that the participants worked in team work while doing shuttle missions and enjoyed experiencing the simulators. It has been observed that by obtaining in-depth information about astronomy from the experts, students have developed their critical, questioning and thinking skills and have the opportunity to obtain detailed information about the professions. They toured the simulated Mars, made a hot air balloon and launched it. They watched a documentary about the stars in the planetarium. The camp enabled the participants to discuss with the experts in depth, to develop their skills such as critical, questioning, and team work, and to learn with fun.

Most of the students stayed away from their families for the first time and this situation enabled them to gain self-confidence. In addition, students' leadership skills have increased. They understood the importance of team work. They had practical space experiences. In addition, positive effects such as happiness and excitement were observed in the eyes of children throughout the camp. The camp has increased students' interest and curiosity in space and astronomy. They developed their problem-solving skills by pushing the limits of their imagination.

Gillette (2013) found a significant difference in favor of the experimental group in his study of the out-of-school learning environment such as the planetarium on the students who participated in the planetarium (experiment group) and did not (control group). He observed the positive effect of planetariums on students' learning. Likewise, in the study of Petrie (2013) with the students and family groups participating in the planetarium program, they stated that the students love these programs and will be interested in astronomy in the future. In the study of Colombo, Silva and Aroca (2010), they investigated the effect of planetariums in teaching astronomy concepts and increasing motivation among students and as a result, they emphasized the increasing importance given to science centers.

In Tal's (2004) study, Astronomy education was organized in space camp Turkey with the participation of high school students from countries such as America, Israel and Turkey. This study aimed to emphasize global friendship and multicultural awareness acquired throughout education. Likewise, In the study of Aktamis, Acar and Unal Coban (2015), the 6th, 7th and 8th grade (11-14 years old), who came from the boarding school with the social services and child protection institution in the space summer camp, consists of 36 students. Participating students learned about astronomy and space at the end of the training and their interest in the subject increased. Along with science space camps, teaching of concepts related to science in a fun way is suggested to students. Deborah Anne Fields (2009) in the study where American high school students' perceptions about the summer astronomy camp and the benefits of the camp were investigated, it was concluded that the students provided peer relationships, personal autonomy and in-depth knowledge of science. As a result of astronomy education, it can be said that the results of this study are similar in terms of increasing peer relations and acquiring in-depth science knowledge.

Most of the studies performed (Yılmaz, 2018; Aksu \& Umdu Topsakal, 2017; Thornburgh, 2017; Carsten-Conner, Larson, Arseneau, \& Herrick, 2015; Henstock, 2014; Small \& Plumber, 2014; Kinsner et al., 2011; Plumber, 2009; Fischer, 1997; Mallon \& Bruce, 1982; Ridky, 1974) out of school learning environments such as planetarium and space camp in astronomy education it supports that it is an effective teaching method.

Apart from the purpose of the research, certain results have been identified. An example of this is Pluto in the most interesting planet category. Since astronomy-related subjects require more abstract, difficult to understand, three-dimensional thinking and seem complicated, it causes misconceptions in students. Many studies (Arıkurt, Durukan, \& Şahin, 2015; Plummer \& Maynard, 2014; Calderón-Canales, Flores-Camacho, \& Gallegos-Cázares, 2013; Kim, Yu, \& Choe, 2011) show that students have misconceptions about astronomy issues.

\section{References}

Aksu, S., \& Umdu Topsakal, Ü. (2017). Planetariums as a source of outdoor learning environment. Educational Research and Reviews, 12, 283-287. https://doi.org/10.5897/ERR2016.2956

Aktamis, H., Acar, E., \& Unal Coban, G. (2015). A summer camp experience of primary student: Let's learn astronomy, explore the space summer camp. Asia-Pacific Forum on Science Learning and Teaching, 16(1), 1.

Arıkurt, E., Durukan, Ü. G., \& Şahin, Ç. (2015). Farklı öğrenim seviyesindeki öğrencilerin astronomi kavramılla ilgili görüşlerinin gelişimsel olarak incelenmesi. Amasya Üniversitesi Ĕgitim Fakültesi Dergisi, 
$4(1), 66-91$

Betz, F. (2011). Managing science: Methodology and organization of research. London: Springer. https://doi.org/10.1007/978-1-4419-7488-4

Calderón-Canales, E., Flores-Camacho, F., \& Gallegos-Cázares, L. (2013). Elementary students' mental models of the solar system. Astronomy Education Review, 12(1), 1-8. https://doi.org/10.3847/AER2012044

Carsten-Corner, L. D., Larson, A. M., Arseneau, J., \& Herrick, R. R. (2015). Elementary student knowledge gains in the digital portable planetarium. Journal of Astronomy \& Earth Sciences Education (JAESE), 2(2), 65-76. https://doi.org/10.19030/jaese.v2i2.9511

Colombo, P. D., Jr., Silva, C. C., \& Aroca, S. C. (2010). Daytime School Guided Visits to an astronomical observatory in Brazil. Astronomy Education Review, 9(1). https://doi.org/10.3847/AER2010017

Davey, L. (1991). The application of Case Study Evaluations. Practical assessment Research \& Evaluation. ISSN: 1531-7714.

Deborah Anne Fields. (2009). What do Students Gain from a Week at Science Camp? Youth perceptions and the design of an immersive, research - oriented astronomy camp. International Journal of Science Education, 31(2), 151-171, https://doi.org/10.1080/09500690701648291

Fischer, M. S. (1997). The effect of Humor On Learning in a Planetarium. Science Education, 81(6), $703-713$. https://doi.org/10.1002/(SICI)1098-237X(199711)81:6<703::AID-SCE7>3.0.CO;2-M

Gillette, S. (2013). The Effects of Seductive Details in An Inflatable Planetarium. Doctoral dissertation, Walden University, Proquest Dissertations Publishing, 3595482.

Henstock, M. (2014). Space camp Turkey. Science Education News, 63(3), 10-15. ISSN: 0048-9603.

Kim, E. S., Yu, H. W., \& Choe, S. U. (2011). Investigation of the 7th grade science-gifted students' understanding about the lunar phase through their own observation and interpretation. Journal of The Korean Earth Science Society, 32(5), 514-520. https://doi.org/10.5467/JKESS.2011.32.5.514

Kinsner, W., Britton, R. N., Cieszecki, J., Ellis, W., Thoren, A., Schor, D., ... Lee, N. C. (2011). A Space Adventure Camp and Pre-University Outreach. https://doi.org/10.24908/pceea.v0i0.3640

Mallon, G. L., \& Bruce, M. H. (1982). Student Achievement and Attitudes in Astronomy: An Experimental Comparison of two planetarium programs. https://doi.org/10.1002/tea.3660190108

Miles, M. B., \& Huberman, A. M. (1994). Qualitative data analysis: An expanded sourcebook (2nd ed.). Thousand Oaks, CA: Sage Publications.

National Research Council. (2009). Learning Science in informal Environments: People, Places, and Pursuits. Committee on Learning Science in Informal Environments. In B. Philip, L. Bruce, W. S. Andrew \& A. F. Michael (Eds.), Board on Science Education, Center for Education Division of Behavioral and Social Sciences and Education. Washington, DC: The National Academies Press. https://doi.org/10.17226/12190

Padalkar, S. (2010). Spatial cognition and visualization in elementary astronomy education. Doctoral dissertation. Tata institute of Fundamental Research, Mumbai.

Percy, J. R. (2006). Teaching astronomy? Why and how? Journal of the American Association of Variable Star Observers, 35(1), 248-254. Retrived from http://adsabs.harvard.edu/full/2006JAVSO..35..248P

Petrie, K. B. (2013). Early Childhood Learning in Preschool Planetarium Programs. Master of arts, University of Washington.

Plumber, J. D. (2009). Early elements students' development of astronomy concepts in the planetarium. Journal of Research in Science Teaching, 46(2), 192-209. https://doi.org/10.1002/tea.20280

Plumber, J. D., \& Maynard, L. (2014). Building a learning progression for celestial motion: An exploration of students' reasoning about the seasons. Journal of Research in Science Teaching, 51(7), 902-929. https://doi.org/10.1002/tea.21151

Plumber, J. D., Schmoll, S., Chun Yu, K., \& Ghent, C. (2015). A Guide to Conducting Educational research in a Planetarium. Planetarium, 44(2), 8-24.

Ridky, R. W. (1974). A study of Planetarium effectiveness on student achievements, Perceptions and retention (p. 21). National Association for Research in science teaching.

Small, K. J., \& Plumber, J. D. (2014). A longitudinal study of early elementary students' understanding of lunar 
phenomena after planetarium and classroom instruction. Planetarian, 43(4), 18-21.

Tal, I. (2004). International Space Course. An Experiment Multi Cultural Distant Learning. 55th International Astronautical in Congress. Vancouver, Canada.

Thornburgh, W. R. (2017). The role of the planetarium in students' attitudes, learning, and thinking about astronomical concepts. Unpublished doctoral dissertation, University of Louisville, Kentucky.

Yıldırım, A., \& Şimşek, H. (2005). Sosyal Bilimlerde Nitel Araştırma Yöntemleri. Ankara: Seçkin Yayıncılık.

Yılmaz, E. (2018). Öğrencilerin uzaya ilişkin ilgi ve kavramlarını geliştirmeye yönelik okul dışı ortamlarla desteklenen bir eylem araştırması. Yüksek lisans tezi, Sakarya Üniversitesi, Sakarya.

\section{Copyrights}

Copyright for this article is retained by the author, with first publication rights granted to the journal.

This is an open-access article distributed under the terms and conditions of the Creative Commons Attribution license (http://creativecommons.org/licenses/by/4.0/). 